\title{
High Occurrence of Shiga Toxin-Producing Escherichia coli in Raw Meat-Based Diets for Companion Animals-A Public Health Issue
}

\author{
Andrea Treier, Roger Stephan (D, Marc J. A. Stevens (D), Nicole Cernela and Magdalena Nüesch-Inderbinen *(i) \\ Institute for Food Safety and Hygiene, Vetsuisse Faculty, University of Zurich, 8057 Zürich, Switzerland; \\ andrea.treier@uzh.ch (A.T.); stephanr@fsafety.uzh.ch (R.S.); marc.stevens@uzh.ch (M.J.A.S.); \\ n.cernela@access.uzh.ch (N.C.) \\ * Correspondence: magdalena.nueesch-inderbinen@uzh.ch; Tel.: +41-44-635-8651
}

check for updates

Citation: Treier, A.; Stephan, R.; Stevens, M.J.A.; Cernela, N.; Nüesch-Inderbinen, M. High Occurrence of Shiga Toxin-Producing Escherichia coli in Raw Meat-Based Diets for Companion Animals-A Public Health Issue. Microorganisms 2021, 9, 1556. https://doi.org/ 10.3390/microorganisms 9081556

Academic Editors: Tim A. McAllister, Flemming Scheutz, Linda Chui, Chad R. Laing, Nicole Van De Kar, Kim Stanford and Patricia Griffin

Received: 2 July 2021

Accepted: 17 July 2021

Published: 21 July 2021

Publisher's Note: MDPI stays neutral with regard to jurisdictional claims in published maps and institutional affiliations.

Copyright: (c) 2021 by the authors. Licensee MDPI, Basel, Switzerland. This article is an open access article distributed under the terms and conditions of the Creative Commons Attribution (CC BY) license (https:// creativecommons.org/licenses/by/ $4.0 /)$.

\begin{abstract}
Feeding pets raw meat-based diets (RMBDs) is becoming increasingly popular but comes with a risk of pathogenic bacteria, including Shiga toxin-producing Escherichia coli (STEC). In humans, STEC may cause gastrointestinal illnesses, including diarrhea, hemorrhagic colitis (HC), and the hemolytic uremic syndrome (HUS). The aim of this study was to evaluate commercially available RMBDs with regard to the occurrence of STEC. Of 59 RMBD samples, 59\% tested positive by realtime PCR for the presence of Shiga toxin genes st $x 1$ and/or st $x 2$. STECs were recovered from $41 \%$ of the 59 samples, and strains were subjected to serotyping and virulence gene profiling, using whole genome sequencing (WGS)-based methods. Of 28 strains, $29 \%$ carried st $x 2 a$ or st $x 2 d$, which are linked to STEC with high pathogenic potential. Twenty different serotypes were identified, including STEC O26:H11, O91:H10, O91:H14, O145:H28, O146:H21, and O146:H28, which are within the most common non-O157 serogroups associated with human STEC-related illnesses worldwide. Considering the low infectious dose and potential severity of disease manifestations, the high occurrence of STEC in RMBDs poses an important health risk for persons handling raw pet food and persons with close contact to pets fed on RMBDs, and is of concern in the field of public health.
\end{abstract}

Keywords: raw meat; pet food; dogs; Shiga toxin; Escherichia coli; public health

\section{Introduction}

Feeding companion animals raw meat has become increasingly popular among cat and dog owners aiming to provide their pets with a natural and healthy diet $[1,2]$. Raw meat-based diets (RMBDs), also known as Biologically Appropriate Raw Food (BARF), include uncooked raw muscle meats, organ meats, and meaty bones of livestock or wild animals, and are mostly based on the by-products of animals slaughtered for human consumption [3,4]. Since RMBDs are not cooked or pasteurized, concerns have been raised regarding bacterial contamination and the possible transmission of pathogens to pets and humans [5-7]. Enterobacteriaceae are the most frequently recovered bacteria from commercially available RMBDs, with a high proportion of sampled RMBDs failing to meet the microbiological standards set out by EC regulation no.1069/2009 in the EU for animal by-products intended for pet food, or the threshold levels for raw human meat products which apply in North America [2,7-9]. Of particular concern, Shiga toxin-producing Escherichia coli (STEC) were identified in $4 \%$ of commercially available RMBDs in the US [10], and contaminated RMBDs have been associated with an outbreak of human STEC infections in the UK [11].

Human infection with STEC is a gastrointestinal illness which may include mildto-severe non-bloody or bloody diarrhea (BD), hemorrhagic colitis (HC), and the lifethreatening hemolytic uremic syndrome (HUS) [12]. STECs are characterized by the proliferation of one or two different types of Shiga toxin encoded by stx genes designated 
stx 1 and stx2, with three stx 1 (stx $1 a$, stx $1 c$ and stx $1 d)$ and ten stx2 (stx2a-stx $2 k$ ) subtypes described so far $[13,14]$. STECs harboring st $x 2 a, s t x 2 c$, and st $x 2 d$ tend to be associated with severe disease, whereas STECs carrying st $2 b$ and st $x 2 e$ are linked to mild clinical symptoms or asymptomatic fecal carriage [15-17]. Furthermore, STEC strains may feature additional genes encoding toxins and adherence factors that influence their pathogenic potential, such as ast $A$ (enteroaggregative $E$. coli heat-stable toxin 1), $c d t$ (cytolethal distending toxin), efa (enterohemorrhagic E. coli factor for adherence), ehxA (enterohemolysin), iha (IrgA homolog adhesin), lpf (long polar fimbriae), saa (STEC autoagglutinating adhesin), and subAB (subtilase cytotoxin) [18-20].

STEC belonging to various serotypes within the O157, O26, O103, O91, and $\mathrm{O} 145$ serogroups constitute the main STEC associated with human infections in the EU and in Switzerland and are considered a major concern to human health in Europe [19,21].

Worldwide, STEC causes an estimated 2.8 million acute illnesses and 3890 HUS cases annually, representing a major public health issue [22]. Although frequently linked to foodborne outbreaks, a majority of STEC infections remain sporadic and are significantly associated with consuming undercooked or raw meat, person-to-person transmission, or contact with animals or their environment $[23,24]$. Although studies demonstrating the occurrence of STEC in RMBDs are rare, they raise the question on the safety of raw pet food and the level of pathogenic potential of STEC occurring in RMBDs [2,10,11].

The aim of this study was to assess the occurrence of STEC isolated from commercially available raw pet food in Switzerland and to characterize the strains by using whole genome analyses.

\section{Materials and Methods}

\subsection{Sample Collection}

During September 2018 and May 2020, a total of 59 RMBD products were purchased from ten different suppliers (designated A-J) either on site in pet-food stores or from certified Swiss RMBD producing enterprises, or in online stores of suppliers located in Switzerland and Germany. The products were purchased frozen or shipped frozen to the laboratory and stored until analysis, according to the recommendations of the suppliers.

The tested products contained either pure muscle or pure organ meat, mixed muscle and organ meat products, or meat supplemented with plant ingredients. Details are listed in Supplementary Table S1.

Products were categorized into those originating from of beef cattle, poultry, horse, lamb, rabbit, venison, and fish. Types of meat within these categories included beef (including rumen and liver) $(n=17)$, chicken $(n=7)$, duck $(n=1)$, quail $(n=1)$, turkey $(n=5)$, ostrich $(n=1)$, horse $(n=8)$, lamb $(n=6)$, rabbit $(n=4)$, reindeer $(n=1)$, moose $(n=1)$, unspecified venison $(n=2)$, salmon $(n=4)$, and perch $(n=1)$.

\subsection{Screening for Stx Genes}

Each sample (10g) was enriched at a 1:10 ratio in Enterobacteriaceae enrichment (EE) broth (Becton, Dickinson, Heidelberg, Germany) for $24 \mathrm{~h}$ at $37^{\circ} \mathrm{C}$. One loopful of each of the enrichment cultures was cultured on sheep blood agar (Difco ${ }^{\mathrm{TM}}$ Columbia Blood Agar Base EH; Becton Dickinson AG, Allschwil, Switzerland), using the streak-plate method. The resulting colonies were washed off with $2 \mathrm{~mL} 0.85 \% \mathrm{NaCl}$. Samples were then screened by real-time PCR for st $x 1$ and st $x 2$, using the Assurance GDS ${ }^{\circledR}$ for Shiga Toxin Genes (Bio Control Systems, Bellevue, WA, USA).

\subsection{Recovery of STEC}

In the event of a stx-positive PCR result, one loopful each of the washed-off suspension was streaked onto on three to five STEC Chromagar plate (CHROMagar, Paris, France) and on three-to-five Brolacin agar plates (Bio-Rad, Hercules, CA, USA) to get single colonies. The plates were incubated overnight at $37^{\circ} \mathrm{C}$. 
From each plate, 20-180 individual colonies were picked (mauve colonies on STEC Chromagar plates; yellow colonies on Brolacin Agar plates) and suspended in $0.5 \mathrm{~mL}$ $0.85 \% \mathrm{NaCl}$. The suspensions were pooled in groups of ten colonies to simplify the screening process. The pooled suspensions were screened for st $x 1$ and st $x 2$ genes by realtime PCR (LightCycler R 2.0 Instrument, Roche Diagnostics Corporation, Indianapolis, IN, USA), using the QuantiFast Multiplex PCR Kit (Qiagen, Hombrechtikon, Switzerland) according to the guidelines of the European Union Reference Laboratory [25]. In the event of a positive PCR result for st $x 1$ or st $x 2$, the pool was taken apart and the ten colonies were tested individually. From plates yielding more than one stx positive colony, one presumptive STEC isolate was randomly chosen for subsequent characterization.

\subsection{DNA Extraction and Whole Genome Sequencing}

The strains were grown on sheep blood agar at $37^{\circ} \mathrm{C}$ overnight prior to DNA isolation, using the DNA blood and tissue kit (Qiagen, Hombrechtikon, Switzerland). The DNA libraries were prepared by using a Nextera DNA Flex Sample Preparation Kit (Illumina, San Diego, CA, USA). Whole-genome sequencing was performed on an Illumina MiniSeq Sequencer (Illumina, San Diego, CA, USA). The Illumina-reads files passed the standard quality checks, using the software package FastQC 0.11.7 (Babraham Bioinformatics, Cambridge, UK), and were assembled by using the Spades 3.14.1based software Shovill 1.0.4 [26,27], using default settings. The assembly was filtered, retaining contigs $>500$ bp and annotated by using the NCBI prokaryotic genome annotation pipeline [28]. Stx types were determined by an in silico PCR, using the perl script in_silico_pcr (https: / / github.com/egonozer/in_silico_pcr, accessed on 20 January 2021), using the option "-m, allow one mismatch" and primer sets described in the EU Reference Laboratory for E. coli manual for stx genes detection [29]. The O and H-types were identified by using SerotypeFinder 2.0 [30]. The virulence gene profiles and antimicrobial resistance genes were determined by using VirulenceFinder 2.0 [31] and Resistance Gene Identifier (RGI) 4.2.2 [32].

The sequence types (STs) of each strain were determined based on seven housekeeping genes, using the tool "MLST" (https://github.com/tseemann/mlst, accessed on 20 January 2021), using PubMLST as the database (https://pubmlst.org/, accessed on 20 January 2021) [33]. The isolates were compared by using core genome MLST (cgMLST) analyses comprising 2513 loci of E. coli, using the Ridom SeqSphereC+ software (version 5.1.0; Ridom GmbH, Münster, Germany). Minimum spanning tree (MST) were generated for visualization of strain relatedness, and the threshold for cluster identification was $\leq 10$ alleles between a pair of isolates, according to the Ridom SeqSphereC + software.

\section{Results}

\subsection{Real-Time Screening for Stx Genes and Isolation of STEC}

By real-time PCR screening of enrichment cultures, st $x 1$ and/or st $x 2$ were detected in $35(59 \%)$ of the 59 raw pet-food samples analyzed in this study. Thereof, the majority $(n=32)$ contained stx 2 alone or in combination with stx1. The distribution of stx genes among the different types and categories of meat is shown in Table 1 and Figure 1. RMBDs containing stx genes were detected in products from nine of ten suppliers (Figure 2). STEC was isolated from 24 of the 35 samples with presumptive presence of STEC, corresponding to a recovery rate of $69 \%$ and an overall STEC prevalence of $41 \%$. Three samples (beef RMBD samples AT 15 and LS 01, and venison RMBD sample AT 11, respectively) contained two or more distinct STEC strains (Table 2). A total of 28 STEC strains were retrieved. The types and categories of meat from which STEC-positive samples were recovered are shown in Table 1 and Figure 1. 
Table 1. Detection of stx genes by PCR and isolation of STEC strains from RMBDs for pets.

\begin{tabular}{|c|c|c|c|c|c|c|c|}
\hline \multirow[b]{3}{*}{$\begin{array}{c}\text { Type of } \\
\text { Meat }\end{array}$} & & \multicolumn{4}{|c|}{ Molecular Detection of stx Genes } & \multicolumn{2}{|c|}{ Isolation of STEC Strains ${ }^{a}$} \\
\hline & \multicolumn{7}{|c|}{ No. of Samples (\%) Positive for } \\
\hline & $\begin{array}{c}\text { No. of } \\
\text { Samples }\end{array}$ & $\begin{array}{c}\text { No. of } \\
\text { st } x \text {-Positive } \\
\text { Samples }(\%)\end{array}$ & st $x 1$ & st $x 2$ & st $x 1$ and $s t x 2$ & $\begin{array}{c}\text { No. of } \\
\text { STEC-Positive } \\
\text { Samples (\%) }\end{array}$ & $\begin{array}{c}\text { No. of STEC } \\
\text { Isolated }\end{array}$ \\
\hline Beef & 17 & $9(53)$ & $0(0)$ & $0(0)$ & $9(53)$ & $5(29)$ & 8 \\
\hline Chicken & 7 & $3(43)$ & $1(14)$ & $1(14)$ & $1(14)$ & $1(14)$ & 1 \\
\hline Duck & 1 & $1(100)$ & $0(0)$ & $0(0)$ & $1(100)$ & $1(100)$ & 1 \\
\hline Horse & 8 & $4(50)$ & $0(0)$ & $2(25)$ & $2(25)$ & $4(50)$ & 4 \\
\hline Lamb & 6 & $6(100)$ & $1(17)$ & $0(0)$ & $5(83)$ & $4(67)$ & 4 \\
\hline Moose & 1 & $1(100)$ & $0(0)$ & $1(100)$ & $0(0)$ & $1(100)$ & 1 \\
\hline Ostrich & 1 & $1(100)$ & $0(0)$ & $0(0)$ & $1(100)$ & $1(100)$ & 1 \\
\hline Perch & 1 & $0(0)$ & $0(0)$ & $0(0)$ & $0(0)$ & $0(0)$ & 0 \\
\hline Quail & 1 & $0(0)$ & $0(0)$ & $0(0)$ & $0(0)$ & $0(0)$ & 0 \\
\hline Rabbit & 4 & $2(50)$ & $0(0)$ & $0(0)$ & $2(50)$ & $2(50)$ & 2 \\
\hline Reindeer & 1 & $1(100)$ & $0(0)$ & $1(100)$ & $0(0)$ & $1(100)$ & 1 \\
\hline Salmon & 4 & $2(50)$ & $1(25)$ & $0(0)$ & $1(25)$ & $1(25)$ & 1 \\
\hline Turkey & 5 & $3(60)$ & $0(0)$ & $0(0)$ & $3(60)$ & $1(20)$ & 1 \\
\hline Venison & 2 & $2(100)$ & $0(0)$ & $1(50)$ & $1(50)$ & $2(100)$ & 3 \\
\hline Total & 59 & 35 (59) & $3(5)$ & $6(10)$ & $26(44)$ & $24(41)$ & 28 \\
\hline
\end{tabular}

${ }^{a}$ PCR positive samples were further cultured and at least one STEC was isolated by growth on Brolacin STEC agar or CHROMagar ${ }^{\mathrm{TM}}$. For details, see text.

(a)

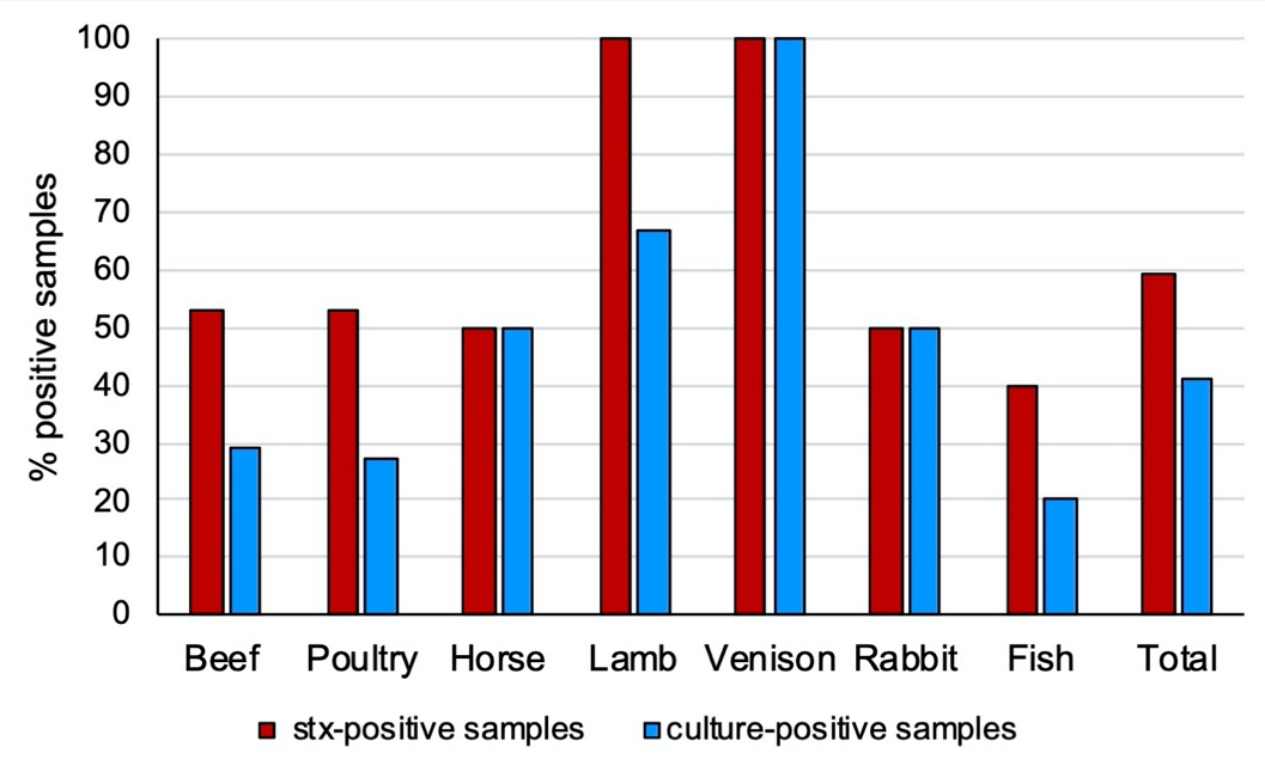

Figure 1. Cont. 
(b)

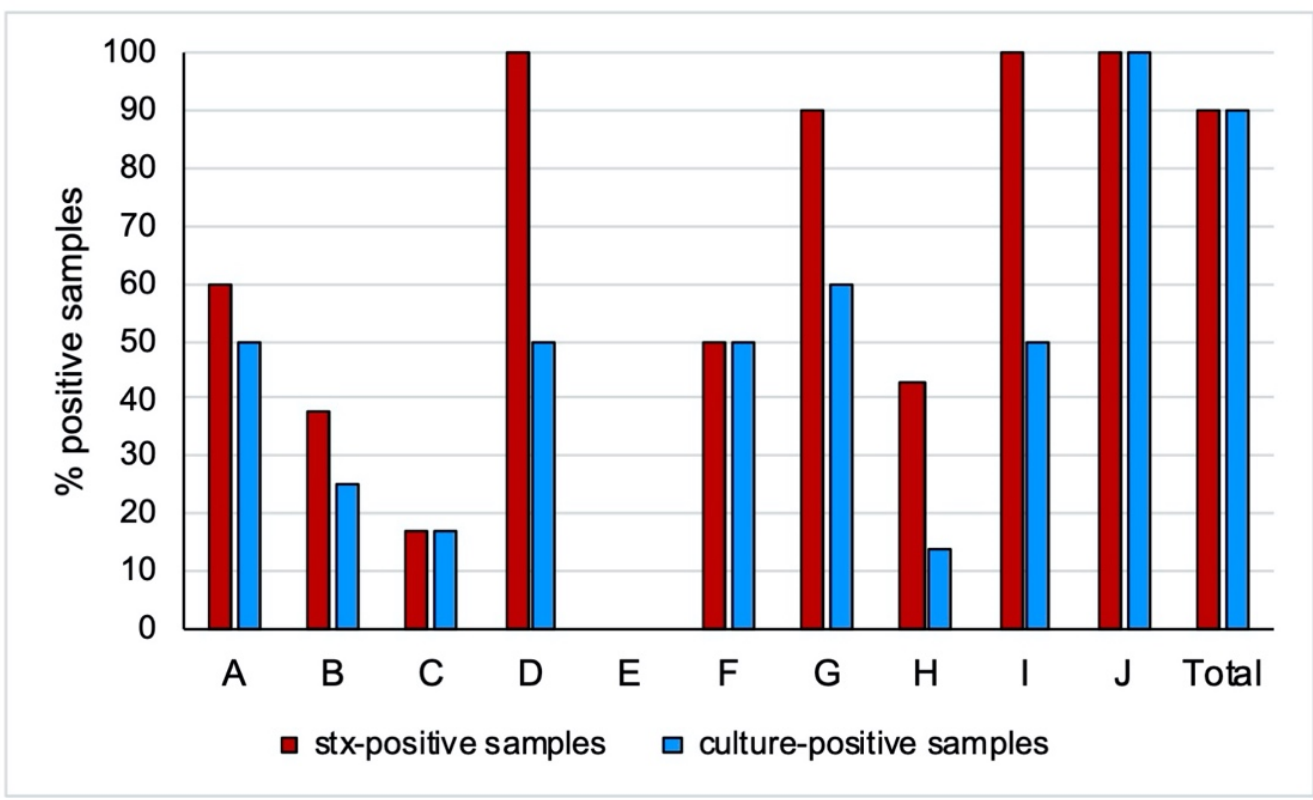

Figure 1. Screening by PCR for Shiga toxin (stx) genes and recovery of Shiga toxin-producing Escherichia coli (STEC) from 59 samples of RMBDs for pets. (a) Percent RMBDs with st $x 1$ and st $x 2$ genes detected in enrichment broth cultures obtained from 59 samples, and percent STEC culture-positive RMBDs. (b) Percent of RMBDs of ten different suppliers A-J containing stx genes and percent of RMBDs contaminated with STEC.

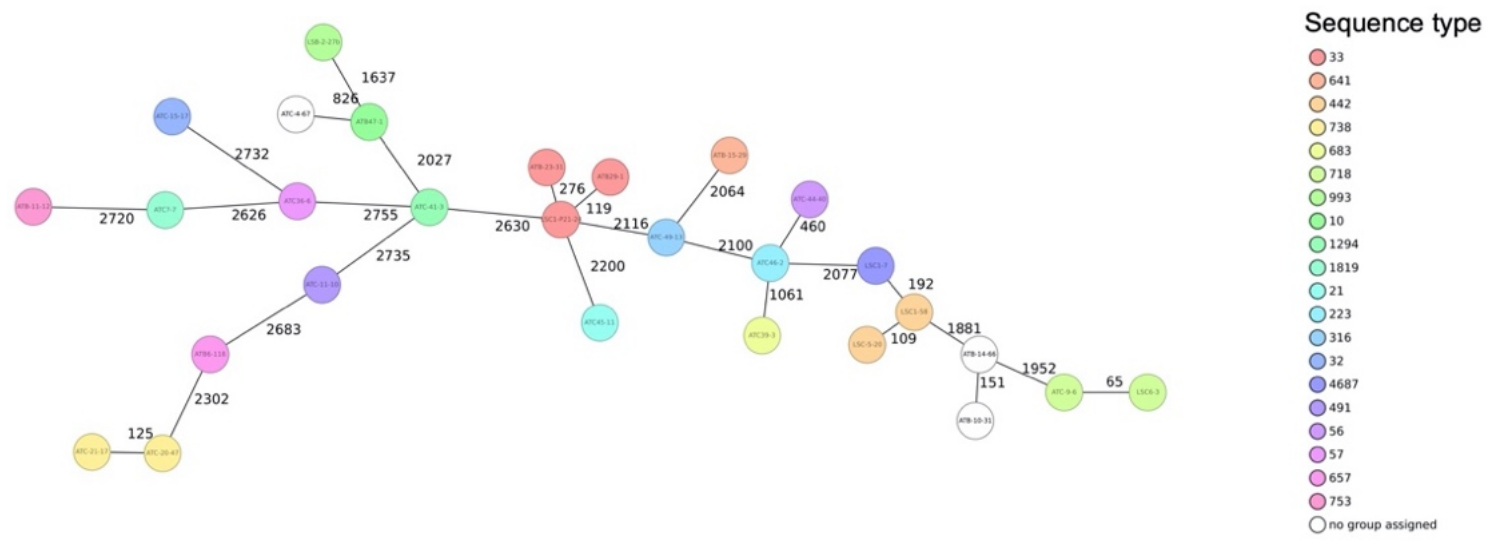

Figure 2. Phylogenetic relationship of 28 Shiga toxin-producing Escherichia coli (STEC) isolated from RMBD for pets based on their multilocus sequence type (MLST) allelic profiles. The minimum spanning tree was generated by using SeqSphere (Ridom $\mathrm{GmbH}$ ). Numbers on connecting lines indicate the number of allele differences between two strains. The colors of the circles represent STs according to the Warwick scheme (http:/ / enterobase.warwick.ac.uk, accessed on 22 January 2021). Strain IDs are indicated in the circles.

\subsection{Serotypes and Stx Subtypes}

Overall, 20 different serotypes were identified among the 28 STEC (Table 2). Serotypes occurring more than once were O91:H14 $(n=3), \mathrm{O} 146: \mathrm{H} 21(n=3), \mathrm{O} 76: \mathrm{H} 19(n=2)$, O113:H21 $(n=2), \mathrm{O} 146: \mathrm{H} 28(n=2)$, and O168:H8 $(n=2)$. All other serotypes were identified in one strain each (Table 2). No STEC O157:H7 was found. Subtyping of the stx genes revealed that six $(21 \%)$ carried stx 1 genes only: stx $1 a(n=2)$ and stx $1 c(n=4)$. Fourteen (50\%) carried stx2 genes only: stx $2 a(n=1), \operatorname{stx} 2 b(n=6)$, stx2d $(n=5)$, stx $2 e(n=2)$, and stx $2 g(n=1)$. Eight $(29 \%)$ harbored combinations of stx 1 and stx 2 genes (Table 2).

A total of eight ( $29 \%$ of all the strains) carried subtypes linked to high pathogenic potential, namely st $2 a(n=3)$ or $s t x 2 d(n=5)$, which were detected among STEC serotypes 
O168:H8 $(n=2)$, O183:H18 $(n=1), \mathrm{O} 91: \mathrm{H} 10(n=1), \mathrm{O} 113: \mathrm{H} 21(n=2), \mathrm{O} 26: \mathrm{H} 11(n=1)$, and O113:H4 $(n=1)$ originating from beef $(n=3)$, duck $(n=1)$, rabbit $(n=1)$, moose $(n=1)$, salmon $(n=1)$, and turkey $(n=1)$. (Table 2$)$. Fourteen $(50 \%)$ isolates harbored the low pathogenic subtypes st $x 2 b$ and st $x 2 e$ and were associated with various serogroups, as listed in Table 2. STEC O168:H8 (strain ID LSC 6-3) isolated from a beef sampled harbored both st $x 2 b$ and st $x d$ (Table 2$)$.

\subsection{Additional Virulence Factor Genes}

Besides Shiga toxin genes, a number of further toxin genes were identified among the strains, including ast $A(n=8), \operatorname{cdtB}(n=1), \operatorname{ehx} A(n=16), \operatorname{sen} B(n=9)$, and $\operatorname{sub} A$ $(n=17)$ (Table 2$)$. The eae gene encoding intimin was detected in two $(7 \%)$ strains and was associated with STEC O145:H28 harboring stx1a (strain ATC 15-17 isolated from beef RMBD), and STEC O26:H11 carrying stx1a and st $2 a$ (strain ATC 45-11isolated from turkey RMBD) (Table 1). Genes encoding other virulence factors thought to be involved in adhesion to the human intestine included cif $(n=2), \operatorname{espI}(n=7), \operatorname{espP}(n=6)$, hra $(n=7)$, iha $(n=25)$, ompT $(n=21)$, and papC $(n=3)$ (Table 2$)$. None of the strains contained the adherence factors eidG and saa. Additionally, epe $A(n=2)$, fyuA $(n=3), \operatorname{gad}(n=25)$, ire $A$ $(n=16)$, iss $(n=23), \operatorname{iucC}(n=9)$, iutA $(n=9), \operatorname{katP}(n=3), \operatorname{kps} E(n=7), \operatorname{lpf} A(n=19)$, sitA $(n=6), \operatorname{terC}(n=28)$, and $\operatorname{traT}(n=25)$ were found.

\subsection{Sequence Types and Phylogenetic Relationship}

Multilocus sequence typing assigned the strains to 20 different STs. One STEC O123:H16 and two STEC O76:H19 (strains ATB 4-67, ATB 10-31, and ATB 14-66, respectively) were not assigned to any ST (Table 2). STs occurring more than once were ST33 $(n=3)$, ST442 $(n=2)$, ST718 $(n=2)$, and ST738 $(n=2)$. The remaining STs occurred only once (Table 2 and Supplementary Table S2).

The population structure of the strains was visualized by constructing a phylogenetic tree based on cgMLST. The isolates grouped according to serotypes and STs, but they were phylogenetically clearly distinct from each other, with $\geq 5$ different alleles between each pair of neighboring isolates (Figure 2). The genomes of strains belonging to ST33, ST442, and ST641 were compared with the available genomes of corresponding STs present in the database of the Swiss National Reference Centre for Enteropathogenic Bacteria and Listeria (NENT) which collects all STEC strains from confirmed human cases nationwide and performs Illumina-based whole-genome sequencing. The cgMLST-based phylogenetic trees are shown in Figure 3 and details are available in Supplementary Table S3). None of the STEC strains belonging to ST33, ST442, or ST642 clustered with a strain in the database, thereby ruling out a direct match with any STEC of those STs reported from a case of human disease in Switzerland. 
Table 2. Characteristics of 28 STEC isolated from RMBD for pets.

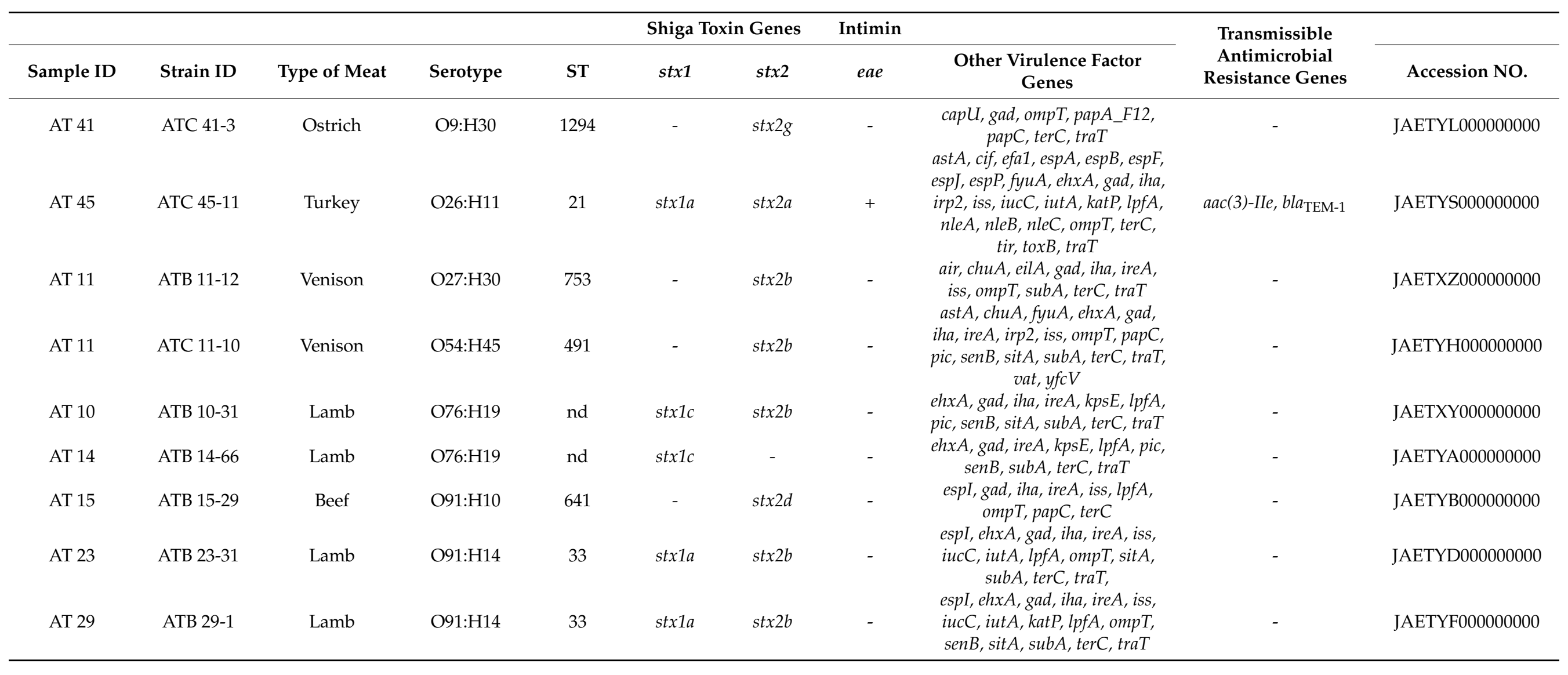


Table 2. Cont.

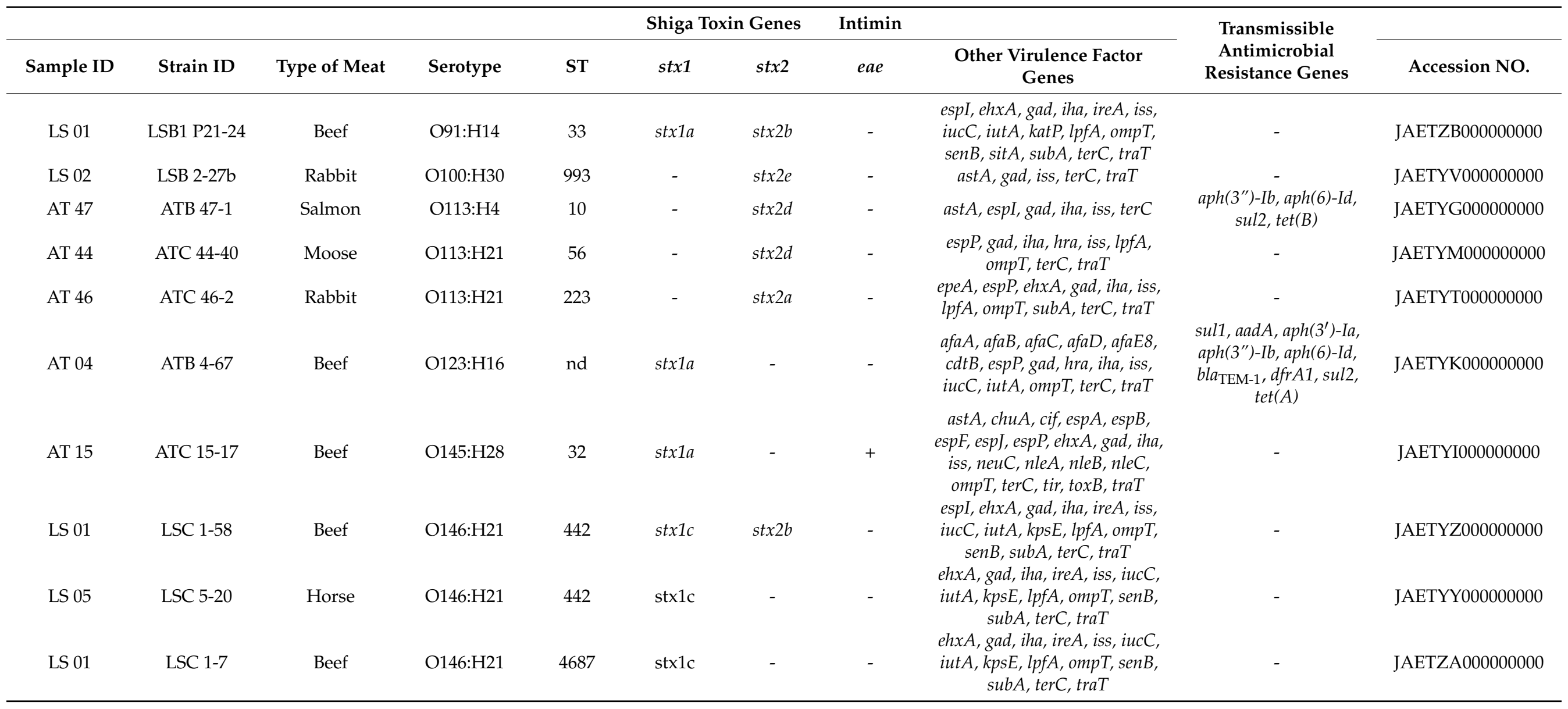


Table 2. Cont.

\begin{tabular}{|c|c|c|c|c|c|c|c|c|c|c|}
\hline \multirow[b]{2}{*}{ Sample ID } & \multirow[b]{2}{*}{ Strain ID } & \multirow[b]{2}{*}{ Type of Meat } & \multirow[b]{2}{*}{ Serotype } & \multirow[b]{2}{*}{ ST } & \multicolumn{2}{|c|}{ Shiga Toxin Genes } & \multicolumn{2}{|c|}{ Intimin } & \multirow{2}{*}{$\begin{array}{c}\text { Transmissible } \\
\text { Antimicrobial } \\
\text { Resistance Genes }\end{array}$} & \multirow[b]{2}{*}{ Accession NO. } \\
\hline & & & & & stx 1 & stx 2 & eae & $\begin{array}{l}\text { Other Virulence Factor } \\
\text { Genes }\end{array}$ & & \\
\hline AT 21 & ATC 21-17 & Venison & O146:H28 & 738 & - & st $x 2 b$ & - & $\begin{array}{c}\text { ast } A, \operatorname{chu} A, \text { hra, iha, ire } A, \text { iss, } \\
\operatorname{lpf} A, \text { omp } T, \operatorname{sub} A, \operatorname{ter} C, \operatorname{traT}, \\
\text { usp }\end{array}$ & - & JAETYJ000000000 \\
\hline AT 20 & ATC 20-47 & Horse & O146:H28 & 738 & - & st $x 2 b$ & - & $\begin{array}{c}\text { ast } A, \operatorname{chu} A, \text { hra, iha, ire } A, \text { iss, } \\
\operatorname{lpf} A, \text { ompT, subA, terC, } \operatorname{traT}, \\
\text { usp }\end{array}$ & - & JAETYP000000000 \\
\hline AT 39 & ATC 39-3 & Horse & O155:H21 & 683 & - & st $x 2 e$ & - & $\begin{array}{c}\text { ast } A, \text { gad, iha, iss, } \operatorname{lpf} A, \text { omp } T, \\
\text { sep } A, \operatorname{ter} C, \operatorname{traT}\end{array}$ & - & JAETYR000000000 \\
\hline AT 49 & ATC 49-13 & Reindeer & O162:H7 & 316 & - & $s t x 2 b$ & - & $\begin{array}{l}\text { ehx } A, \text { gad, iha, ire } A, \text { iss, } \operatorname{lpf} A, \\
\text { omp } T, \text { subA, terC, traT }\end{array}$ & - & JAETYN000000000 \\
\hline LS 06 & LSC 6-3 & Beef & O168:H8 & 718 & - & $s t x 2 b / 2 d$ & - & gad, iha, hra, lpfA, terC, traT & $\begin{array}{l}\text { aph(6)-Id, aph(3")-Ib, } \\
\text { sul2, tet(B) }\end{array}$ & JAETZC000000000 \\
\hline AT 09 & ATC 9-6 & Duck & O168:H8 & 718 & - & $s t x 2 d$ & - & gad, hra, iha, lpfA, terC, traT & $\begin{array}{l}\operatorname{aph}\left(3^{\prime \prime}\right)-I b, \operatorname{aph}(6)-I d, \\
\operatorname{sul} 2, \operatorname{tet}(B)\end{array}$ & JAETYO000000000 \\
\hline AT 07 & ATC 7-7 & Horse & O166:H28 & 1819 & stx $1 c$ & $s t x 2 b$ & - & $\begin{array}{c}\text { air, chuA, eilA, ehx } A, \text { gad, iha, } \\
\text { hra, ire } A, \text { iss, iucC, iut } A, \operatorname{kps} E, \\
\text { omp } T, \operatorname{sen} B, \operatorname{sit} A, \operatorname{sub} A, \operatorname{ter} C, \\
\operatorname{tra} T\end{array}$ & 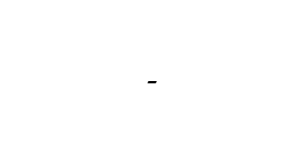 & JAETYU000000000 \\
\hline AT 36 & ATC 36-6 & Chicken & O176:H4 & 57 & stxic & - & - & $\begin{array}{c}\text { chuA, espI, fyuA, ehxA, gad, } \\
\text { iha, ireA, irp2, iss, } k p s E, \operatorname{subA}, \\
\operatorname{ter} C\end{array}$ & - & JAETYQ000000000 \\
\hline AT 06 & АТВ 6-118 & Beef & O183:H18 & 657 & stx1a & st $x 2 a$ & - & $\begin{array}{c}\text { chuA, cvaC, epe } A, \operatorname{esp} P, \operatorname{ehx} A, \\
\text { iha, iss, } \operatorname{lpf} A, \text { omp } T, \operatorname{sub} A, \operatorname{ter} C, \\
\operatorname{traT}\end{array}$ & $\begin{array}{c}a p h\left(3^{\prime \prime}\right)-I b, a p h(6)-I d \\
b l a \mathrm{TEM}-1\end{array}$ & JAEUYO000000000 \\
\hline
\end{tabular}




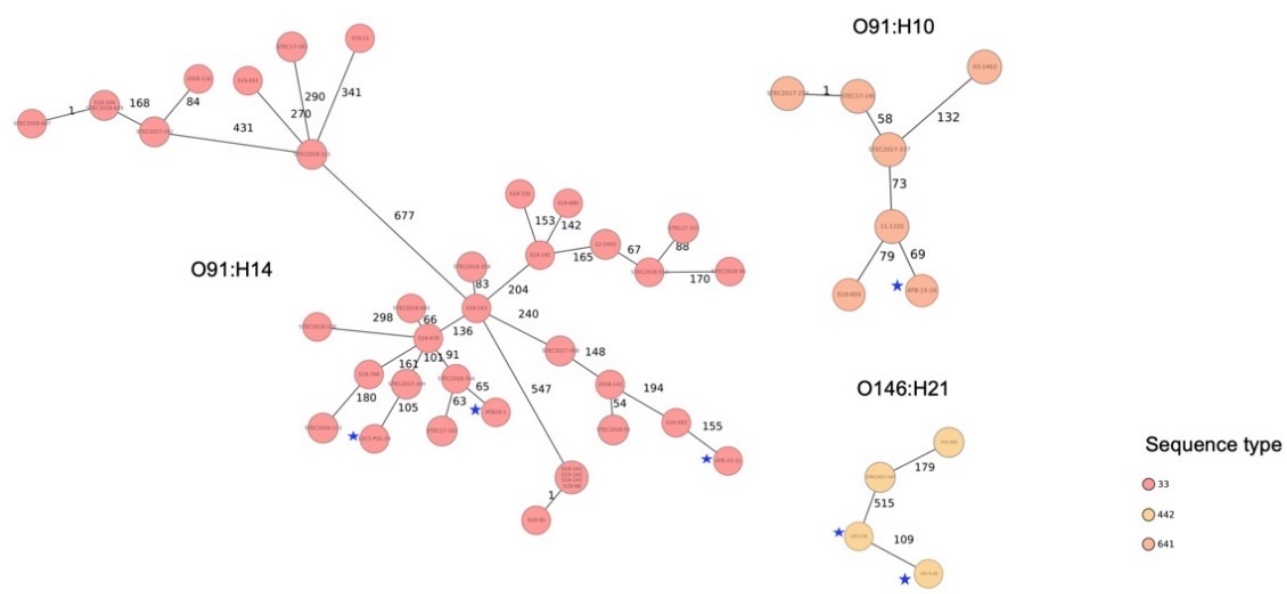

Figure 3. Minimum-spanning trees based on cgMLST allelic profiles of six Shiga toxin-producing Escherichia coli (STEC) isolated from RMBD for pets and genome-sequenced clinical STEC available in the database of the Swiss National Reference Centre for Enteropathogenic Bacteria and Listeria (NENT) in Switzerland. The numbers on connecting lines represent the number of allelic differences between two strains. Strains from this study are indicated with a star.

\subsection{Transmissible Antimicrobial Resistance Genes}

Among the 28 STEC strains, a total of six (21\%) carried multiple transmissible AMR (Table 2). Genes encompassed aminoglycoside resistance genes aac(3)-IIe $(n=1)$, aadA $(n=1)$, $\operatorname{aph}\left(3^{\prime}\right)-I a(n=1), a p h\left(3^{\prime \prime}\right)-I b(n=2)$, and $\left.\operatorname{aph}(6)-I d\right)(n=4)$; sulphonamide resistance genes sul1 $(n=1)$ and sul2 $(n=4)$; trimethoprim resistance gene $\operatorname{drfA1}(n=1)$; and tetracycline resistance genes tet $(A)(n=1)$ and tet $(B)(n=3)$. Two strains (ATB 4-67 and ATB 6-118, respectively) carried the $B$-lactamase gene $b l a_{\mathrm{TEM}-1}$. The distribution of transmissible AMR genes among the STEC strains is given in Table 2.

\section{Discussion}

While recent years have seen a rise in popularity of feeding pets RMBDs, there is rising concern that this trend may come with the risk of exposure to zoonotic pathogens, including STECs. STECs constitute part of the flora of the gastrointestinal tract of a variety of healthy domestic and wild animals and may therefore contaminate meat during slaughter, evisceration, processing, and packing $[1,2,34]$.

In this study, the presence of stx 1 and st $x 2$ genes was detected in $59 \%$ of the enrichment cultures, indicating that the overall contamination of STEC among RMBDs is high. In the majority $(69 \%)$ of the st $x$-positive samples, the isolation of STEC strains confirmed the presence of the stx genes in viable bacterial cells. With an overall prevalence of $41 \%$, the level of STEC contamination in the present study is considerably higher than what another study found previously, where STEC was isolated from $4 \%$ of raw pet food in the US [10]. It is also higher than the prevalence of $14 \%$ reported during an investigation of raw meat for dogs in the UK [11]. However, comparative data are still scarce, and discrepancies between results of different studies may be due to differences in the testing methodologies. Nevertheless, the present study provides evidence that the occurrence of STEC in RMBDs may currently be underestimated.

The pathogenic potential of STEC may vary according to the presence or absence of a variety of virulence factors. Thus, in addition to serotyping, comprehensive virulence gene profiling is important for risk assessment.

Whole-genome sequencing revealed a high diversity of serotypes that included STEC O26:H11, O91:H10, O91:H14, O145:H28, O146:H21, and O146:H28, which are within the most common non-O157 serogroups associated with human illness in Europe and Switzerland $[19,21,35]$. The most frequently identified serotypes in the present study were O91:H14 and O146:H21. STEC O91:H14 is a causative agent of mild-to-severe diarrhea and abdominal pain [21,36-38], whereas O146:H21 is also found in healthy human carriers [39]. 
Notably, the serotype most frequently associated with HC and HUS, STEC O157:H7, was not detected in the present study, indicating that STEC O157:H7 may not be considered a suitable marker for STEC detection in RMBDs.

In our study, we found that $29 \%$ of the STEC isolated from RMBD harbored st $x 2 a$ or $s t x 2 d$, which are the stx subtypes that have the strongest association with HUS [14].

Other toxin genes, including $e h x A$ and $s u b A$ found in $57 \%$ and $61 \%$ of the STEC in this study, are considered important virulence markers for STEC pathogenesis and are frequently detected among human clinical isolates [21,35].

Despite the vast majority (93\%) of the strains being negative for the eae gene, 25 of the 28 strains harbored iha, which is thought to contribute to pathogenicity of eae-negative STEC by facilitating attachment to intestinal cells [40]. Taken together, our data indicate that the STECs occurring in RMBDs have the potential to cause disease in humans.

By contrast, STEC-related illness appears to be rare in companion animals [41]. However, there are several studies that provide evidence for the intestinal carriage of STEC in dogs and cats, highlighting their potential epidemiological role as a source for human STEC infections [42-45]. Hence, it is possible that pets fed RMBDs contaminated with STEC could serve as asymptomatic shedders through their feces, transmitting the pathogen to humans and into the environment.

Interestingly, ten (36\%) strains harbored one or more virulence factors, namely fyuA, $k p s E$, and $p a p C$, which are characteristic of extra-intestinal pathogenic E. coli (ExPEC), including uropathogenic E. coli (UPEC) [46-48]. STEC/ExPEC hybrid strains are rarely reported, but, nevertheless, they must be considered high-risk pathogens due to the possibility of a systemic infection in combination with gastrointestinal disease [49]. Furthermore, papC and fyuA are also prevalent among E. coli causing urinary tract infection (UTI) in cats and dogs [50,51]. Therefore, our data indicate that a subset of STEC present in RMBDs may have the potential to cause disease in pets as well as in humans.

Finally, in this study, six (21\%) strains, including one STEC/ExPEC strain, carried two or more transmissible AMR genes, predominantly genes conferring resistance to aminoglycosides, which are antimicrobials categorized by the World Health Organization (WHO) as critically important in human medicine [52]. These findings are consistent with previous data that document the presence of AMR genes on mobile genetic elements in STEC [53]. AMR in STEC is worrisome because of the likelihood of horizontal transfer of resistance genes to other pathogens. In view of the ongoing global antimicrobial resistance problem, feeding RMBD to dogs that are undergoing antimicrobial treatment should be reconsidered in order to avoid selection and dissemination of AMR bacteria.

\section{Conclusions}

This study identified commercially available RMBDs as a potential source of STEC, including strains with serotypes, st $x$ subtypes, and other virulence traits that are associated with human disease, such as BD, HC, and HUS. In view of the low infectious dose and potential severity of disease manifestations, the high occurrence of potentially harmful STEC in RMBDs represents a risk of infection for persons handling raw pet food and for persons with close contact to pets fed on RMBDs. Our data provide further evidence for the public health risks of raw feeding and highlight the importance of promoting awareness among veterinary and public-health agencies, RMBD suppliers, and pet owners, with the need to focus on safe and hygienic handling of RMBD to protect human and animal health.

Supplementary Materials: The following are available online at https:/ /www.mdpi.com/article/ 10.3390/microorganisms9081556/s1. Table S1: Sample analysis. Table S2: Phylogenetic analysis I. Table S3: Phylogenetic analysis II.

Author Contributions: Conceptualization, A.T. and R.S.; methodology, A.T. and N.C.; software, M.J.A.S.; formal analysis, A.T., M.N.-I. and M.J.A.S.; investigation, A.T.; resources, R.S.; data curation, M.J.A.S.; writing—original draft preparation, A.T. and M.N.-I.; writing—review and editing, M.N.-I. 
and R.S.; visualization, M.J.A.S.; supervision, R.S.; project administration, R.S. All authors have read and agreed to the published version of the manuscript.

Funding: This research received no external funding.

Institutional Review Board Statement: Not applicable.

Informed Consent Statement: Not applicable.

Data Availability Statement: This whole-genome shotgun project was deposited at DDBJ/ENA/ GenBank under the accession numbers JAETXY000000000-JAEUYO000000000. The versions described in this paper are versions JAETXY000000000.1-JAEUYO000000000.1 (https:/ / www.ncbi.nlm. nih.gov / nuccore, accessed on 1 July 2021). Raw sequence data are also available in the Sequence Read Archive (SRA) of the NCBI under BioProject no. PRJNA694525 (https: / www.ncbi.nlm.nih.gov/sra/, accessed on 1 July 2021).

Acknowledgments: This work was partly supported by the Swiss Federal Office of Public Health, Division Communicable Diseases.

Conflicts of Interest: The authors declare no conflict of interest.

\section{References}

1. O'Halloran, C. Raw food diets for companion carnivores: An untapped panacea or a disaster waiting to happen. Companion Anim. 2020, 25, 1-5. [CrossRef]

2. Davies, R.H.; Lawes, J.R.; Wales, A.D. Raw diets for dogs and cats: A review, with particular reference to microbiological hazards. J. Small Anim. Pract. 2019, 60, 329-339. [CrossRef] [PubMed]

3. Freeman, L.M.; Chandler, M.L.; Hamper, B.A.; Weeth, L.P. Current knowledge about the risks and benefits of raw meat-based diets for dogs and cats. J. Am. Vet. Med. Assoc. 2013, 243, 1549-1558. [CrossRef]

4. Dillitzer, N.; Becker, N.; Kienzle, E. Intake of minerals, trace elements and vitamins in bone and raw food rations in adult dogs. Br. J. Nutr. 2011, 106, S53-S56. [CrossRef]

5. Hellgren, J.; Hästö, L.S.; Wikström, C.; Fernström, L.L.; Hansson, I. Occurrence of Salmonella, Campylobacter, Clostridium and Enterobacteriaceae in raw meat-based diets for dogs. Vet. Rec. 2019, 184, 442. [CrossRef]

6. van Bree, F.P.J.; Bokken, G.C.A.M.; Mineur, R.; Franssen, F.; Opsteegh, M.; van der Giessen, J.W.B.; Lipman, L.J.A.; Overgaauw, P.A.M. Zoonotic bacteria and parasites found in raw meat-based diets for cats and dogs. Vet. Rec 2018, 182, 50. [CrossRef] [PubMed]

7. Weese, J.S.; Rousseau, J.; Arroyo, L. 2005 Bacteriological evaluation of commercial canine and feline raw diets. Can. Vet. J. 2018, $46,513-516$.

8. Anonymous. Commission Regulation (EU) No 142/2011 of 25 February 2011 implementing Regulation (EC) No $1069 / 2009$ of the European Parliament and of the Council laying down health rules as regards animal by-products and derived products not intended for human consumption and implementing Council Directive 97/78/EC as regards certain samples and items exempt from veterinary checks at the border under that Directive. Off. J. Eur. Commun. 2011, 54, 1-254.

9. Finley, R.; Reid-Smith, R.; Weese, J.S. Human health implications of Salmonella-contaminated natural pet treats and raw pet food. Clin. Infect. Dis. 2006, 42, 686-691. [CrossRef]

10. Nemser, S.M.; Doran, T.; Grabenstein, M.; McConnell, T.; McGrath, T.; Pamboukian, R.; Smith, A.C.; Achen, M.; Danzeisen, G.; Kim, S.; et al. Investigation of Listeria, Salmonella, and toxigenic Escherichia coli in various pet foods. Foodborne Pathog. Dis. 2014, 11, 706-709. [CrossRef]

11. Byrne, L.; Aird, H.; Jorgensen, F.; Kaindama, L.; Jenkins, C. Investigation into An Outbreak of Shiga Toxin Producing Escherichia coli (STEC) O157 PT 21/28 Stx2 in England, August 2017; Public Health England Publications: London, UK, 2018.

12. Karch, H.; Tarr, P.I.; Bielaszewska, M. Enterohaemorrhagic Escherichia coli in human medicine. Int. J. Med. Microbiol. 2005, 295, 405-418. [CrossRef]

13. Yang, X.; Bai, X.; Zhang, J.; Sun, H.; Fu, S.; Fan, R.; He, X.; Scheutz, F.; Matussek, A.; Xiong, Y. Escherichia coli strains producing a novel Shiga toxin 2 subtype circulate in China. Int. J. Med. Microbiol. 2020, 310, 151377. [CrossRef]

14. Scheutz, F. Taxonomy meets public health: The case of Shiga toxin-producing Escherichia coli. Microbiol. Spectr. 2014, 2. [CrossRef]

15. Fuller, C.A.; Pellino, C.A.; Flagler, M.J.; Strasser, J.E.; Weiss, A.A. Shiga toxin subtypes display dramatic differences in potency. Infect. Immun. 2011, 79, 1329-1337. [CrossRef] [PubMed]

16. Friedrich, A.W.; Bielaszewska, M.; Zhang, W.L.; Pulz, M.; Kuczius, T.; Ammon, A.; Karch, H. Escherichia coli harboring Shiga toxin 2 gene variants: Frequency and association with clinical symptoms. J. Infect. Dis. 2002, 185, 74-84. [CrossRef]

17. Stephan, R.; Hoelzle, L.E. Characterization of Shiga toxin type 2 variant B-subunit in Escherichia coli strains from asymptomatic human carriers by PCR-RFLP. Lett. Appl. Microbiol. 2000, 31, 139-142. [CrossRef] [PubMed]

18. Kaper, J.B.; Nataro, J.P.; Mobley, H.L. Pathogenic Escherichia coli. Nat. Rev. Microbiol. 2004, 2, 123-140. [CrossRef] [PubMed] 
19. Koutsoumanis, K.; Allende, A.; Alvarez-Ordóñez, A.; Bover-Cid, S.; Chemaly, M.; Davies, R.; De Cesare, A.; Herman, L.; Hilbert, F. Pathogenicity assessment of Shiga toxin-producing Escherichia coli (STEC) and the public health risk posed by contamination of food with STEC. EFSA J. 2020, 18, e05967.

20. Paton, A.W.; Srimanote, P.; Talbot, U.M.; Wang, H.; Paton, J.C. A new family of potent AB(5) cytotoxins produced by Shiga toxigenic Escherichia coli. J. Exp. Med. 2004, 200, 35-46. [CrossRef]

21. Nüesch-Inderbinen, M.; Morach, M.; Cernela, N.; Althaus, D.; Jost, M.; Mäusezahl, M.; Bloomberg, G.; Stephan, R. Serotypes and virulence profiles of Shiga toxin-producing Escherichia coli strains isolated during 2017 from human infections in Switzerland. Int. J. Med. Microbiol. 2018, 308, 933-939. [CrossRef]

22. Majowicz, S.E.; Scallan, E.; Jones-Bitton, A.; Sargeant, J.M.; Stapleton, J.; Angulo, F.J.; Yeung, D.H.; Kirk, M.D. Global incidence of human Shiga toxin-producing Escherichia coli infections and deaths: A systematic review and knowledge synthesis. Foodborne Path. Dis. 2014, 11, 447-455. [CrossRef] [PubMed]

23. Joseph, A.; Cointe, A.; Mariani Kurkdjian, P.; Rafat, C.; Hertig, A. Shiga toxin-associated hemolytic uremic syndrome: A narrative review. Toxins 2020, 12, 67. [CrossRef] [PubMed]

24. Kintz, E.; Brainard, J.; Hooper, L.; Hunter, P. Transmission pathways for sporadic Shiga-toxin producing E. coli infections: A systematic review and meta-analysis. Int. J. Hyg. Environ. Health 2017, 220, 57-67. [CrossRef]

25. EURL (European Union Reference Laboratory). Identification and Characterization of Verocytotoxin-Producing Escherichia coli (VTEC) by PCR Amplification of the Main Virulence Genes. 2013. Available online: http://old.iss.it/binary/vtec/cont/EU_RL_ VTEC_Method_01_Rev_0.pdf (accessed on 1 June 2020).

26. Seemann, T. 2019 Shovill. Available online: https://github.com/tseemann/shovill (accessed on 20 January 2021).

27. Bankevich, A.; Nurk, S.; Antipov, D.; Gurevich, A.A.; Dvorkin, M.; Kulikov, A.S.; Lesin, V.M.; Nikolenko, S.I.; Pham, S.; Prjibelski, A.D.; et al. SPAdes: A new genome assembly algorithm and its applications to single-cell sequencing. J. Comput. Biol. 2012, 19, 455-477. [CrossRef]

28. Tatusova, T.; DiCuccio, M.; Badretdin, A.; Chetvernin, V.; Nawrocki, E.P.; Zaslavsky, L.; Lomsadze, A.; Pruitt, K.D.; Borodovsky, M.; Ostell, J. NCBI prokaryotic genome annotation pipeline. Nucleic Acids Res. 2016, 44, 6614-6624. [CrossRef]

29. EURL (European Union Reference Laboratory). Identification of the Subtypes of Verocytotoxin Encoding Genes (vtx) of Escherichia coli by Conventional PCR; EU-RL VTEC_Method_006_Rev 1; EU Reference Laboratory for E. coli. 2013. Available online: https:/ / www.iss.it/documents/20126/1049000/EU_RL_VTEC_Method_06_Rev_1.pdf/1ad8f0c6-8a1b-21c7-dddb-4af2 8f440822? $\mathrm{t}=1576447091624$ (accessed on 1 June 2020).

30. Joensen, K.G.; Tetzschner, A.M.; Iguchi, A.; Aarestrup, F.M.; Scheutz, F. Rapid and easy in silico serotyping of Escherichia coli isolates by use of whole-genome sequencing data. J. Clin. Microbiol. 2015, 53, 2410-2426. [CrossRef]

31. Joensen, K.G.; Scheutz, F.; Lund, O.; Hasman, H.; Kaas, R.S.; Nielsen, E.M.; Aarestrup, F.M. Real-time whole-genome sequencing for routine typing, surveillance, and outbreak detection of verotoxigenic Escherichia coli. J. Clin. Microbiol. 2014, 52, 1501-1510. [CrossRef]

32. Bortolaia, V.; Kaas, R.S.; Ruppe, E.; Roberts, M.C.; Schwarz, S.; Cattoir, V.; Philippon, A.; Allesoe, R.L.; Rebelo, A.R.; Florensa, A.F.; et al. ResFinder 4.0 for predictions of phenotypes from genotypes. J. Antimicrob Chemother. 2020, 75, 3491-3500. [CrossRef]

33. Jolley, K.A.; Maiden, M.C. BIGSdb: Scalable analysis of bacterial genome variation at the population level. BMC Bioinform. 2010, 11, 595. [CrossRef] [PubMed]

34. Karmali, M.A.; Gannon, V.; Sargeant, J.M. Verocytotoxin-producing Escherichia coli (VTEC). Vet. Microbiol. 2010, 140, 360-370. [CrossRef]

35. Fierz, L.; Cernela, N.; Hauser, E.; Nüesch-Inderbinen, M.; Stephan, R. Characteristics of Shigatoxin-producing Escherichia coli strains isolated during 2010-2014 from human infections in Switzerland. Front. Microbiol. 2017, 8, 1471. [CrossRef] [PubMed]

36. Feng, P.C.H.; Delannoy, S.; Lacher, D.W.; Bosilevac, J.M.; Fach, P.; Beutin, L. Shiga toxin-producing serogroup O91 Escherichia coli strains isolated from food and environmental samples. Appl. Environ. Microbiol. 2017, 83, e01231-17. [CrossRef]

37. Maeda, E.; Murakami, K.; Etoh, Y.; Onozuka, D.; Sera, N.; Asoshima, N.; Honda, M.; Narimatsu, H.; Iyoda, S.; Watahiki, M.; et al. Does sequence type 33 of Shiga toxin-producing Escherichia coli O91 cause only mild symptoms? J. Clin. Microbiol. 2015, 53, 362-364. [CrossRef] [PubMed]

38. Mellmann, A.; Fruth, A.; Friedrich, A.W.; Wieler, L.H.; Harmsen, D.; Werber, D.; Middendorf, B.; Bielaszewska, M.; Karch, H. Phylogeny and disease association of Shiga toxin-producing Escherichia coli O91. Emerg. Infect. Dis. 2009, 15, $1474-1477$. [CrossRef] [PubMed]

39. Stephan, R.; Untermann, F. Virulence factors and phenotypical traits of verotoxin-producing Escherichia coli strains isolated from asymptomatic human carriers. J. Clin. Microbiol. 1999, 37, 1570-1572. [CrossRef] [PubMed]

40. Tarr, P.I.; Bilge, S.S.; Vary, J.C.; Jelacic, S.; Habeeb, R.L.; Ward, T.R.; Baylor, M.R.; Besser, T.E. Iha: A novel Escherichia coli O157: H7 adherence-conferring molecule encoded on a recently acquired chromosomal island of conserved structure. Infect. Immun. 2000, 68, 1400-1407. [CrossRef]

41. Beutin, L.; Geier, D.; Steinrück, H.; Zimmermann, S.; Scheutz, F. Prevalence and some properties of verotoxin (Shiga-like toxin)-producing Escherichia coli in seven different species of healthy domestic animals. J. Cin. Microbiol. 1993, 31, $2483-2488$. [CrossRef]

42. Kim, J.S.; Lee, M.S.; Kim, J.H. Recent updates on outbreaks of Shiga toxin-producing Escherichia coli and its potential reservoirs. Front. Cell Infect. Microbiol. 2020, 10, 273. [CrossRef] 
43. Galarce, N.; Escobar, B.; Sánchez, F.; Paredes-Osses, E.; Alegría-Morán, R.; Borie, C. Virulence genes, Shiga toxin subtypes, serogroups, and clonal relationship of Shiga toxin-producing Escherichia coli strains isolated from livestock and companion animals. Animals 2019, 9, 733. [CrossRef]

44. Bentancor, A.; Rumi, M.V.; Carbonari, C.; Gerhardt, E.; Larzábal, M.; Vilte, D.A.; Pistone-Creydt, V.; Chinen, I.; Ibarra, C.; Cataldi, A.; et al. Profile of Shiga toxin-producing Escherichia coli strains isolated from dogs and cats and genetic relationships with isolates from cattle, meat and humans. Vet. Microbiol. 2012, 156, 336-342. [CrossRef]

45. Bentancor, A.; Rumi, M.V.; Gentilini, M.V.; Sardoy, C.; Irino, K.; Agostini, A.; Cataldi, A. Shiga toxin-producing and attaching and effacing Escherichia coli in cats and dogs in a high hemolytic uremic syndrome incidence region in Argentina. FEMS Microbiol. Lett. 2007, 267, 251-256. [CrossRef] [PubMed]

46. Spurbeck, R.R.; Dinh, P.C.; Walk, S.T.; Stapleton, A.E.; Hooton, T.M.; Nolan, L.K.; Kim, K.S.; Johnson, J.R.; Mobley, H.L.T. Escherichia coli isolates that carry vat, fyuA, chuA, and $y f c V$ efficiently colonize the urinary tract. Infect. Immun. 2012, 80, 4115-4122. [CrossRef] [PubMed]

47. Johnson, J.R.; Stell, A.L. Extended virulence genotypes of Escherichia coli strains from patients with urosepsis in relation to phylogeny and host compromise. J. Infect. Dis. 2000, 181, 261-272. [CrossRef]

48. Malberg Tetzschner, A.M.; Johnson, J.R.; Johnston, B.D.; Lund, O.; Scheutz, F. In silico genotyping of Escherichia coli isolates for extraintestinal virulence genes by use of whole-genome sequencing data. J. Clin. Microbiol. 2020, 58, e01269-20. [CrossRef]

49. Santos, A.C.M.; Santos, F.F.; Silva, R.M.; Gomes, T.A.T. Diversity of hybrid- and hetero-pathogenic Escherichia coli and their potential implication in more severe diseases. Front. Cell. Infect. Microbiol. 2020, 10, 339. [CrossRef] [PubMed]

50. Zogg, A.L.; Zurfluh, K.; Schmitt, S.; Nüesch-Inderbinen, M.; Stephan, R. Antimicrobial resistance, multilocus sequence types and virulence profiles of ESBL producing and non-ESBL producing uropathogenic Escherichia coli isolated from cats and dogs in Switzerland. Vet. Microbiol. 2018, 216, 79-84. [CrossRef] [PubMed]

51. Siqueira, A.K.; Ribeiro, M.G.; Leite, D.S.; Tiba, M.R.; Moura, C.; Lopes, M.D.; Prestes, N.C.; Salerno, T.; Silva, A.V. Virulence factors in Escherichia coli strains isolated from urinary tract infection and pyometra cases and from feces of healthy dogs. Res. Vet. Sci. 2009, 86, 206-210. [CrossRef]

52. World Health Organization. Critically Important Antimicrobials for Human Medicine 6th Revision; World Health Organization: Geneva, Switzerland, 2019. Available online: https://www.who.int/publications/i/item/9789241515528 (accessed on 1 March 2021).

53. Mir, R.A.; Kudva, I.T. Antibiotic-resistant Shiga toxin-producing Escherichia coli: An overview of prevalence and intervention strategies. Zoonoses Public Health. 2019, 66, 1-13. [CrossRef] [PubMed] 